\title{
The Tibetan Tulkus. An Interview with Ven. Geshe Lhakdor
}

\section{Maksymilian WocH}

\begin{abstract}
The interview with Venerable Geshe Lhakdor, the director of LTWA (Library of Tibetan Works and Archives) is the result of the fieldwork on tulkus which I have been carrying out since January of 2018 in India. It forms part of a $\mathrm{PhD}$ project, focusing on the question of how the institution of tulku (sprul sku), which is one of the main characteristics of Tibetan Buddhism, is perceived by Tibetans in exile, in the context of the controversy with the double choosing of the Panchen Lamas.

In the paper the interview will be presented with the preceding historical and methodological introduction and then summarized in the commentary.
\end{abstract}

Keywords: Tulku, Panchen Lama, culture, politics

Maksymilian WocH, religious scholar, anthropologist, $\mathrm{PhD}$ student of Philosophical Faculty UJ, researcher on Tibetan culture, Buddhist philosophy and the phenomenon of the tulku. Since 2018, he has conducted fieldwork in India and Nepal within the Tibetan diaspora. E-MAIL: maksymilianwoch@gmail.com 


\section{The Panchen Lamas of Tibet}

Panchen Lamas are regarded as very high reincarnated lamas, considered to be worldly emanations of Buddha Amitabha ('od dpag med). The title of "Panchen" (paN chen), which means a "Great Scholar", was bestowed upon Lobsang Chokeyi Gyaltsen (blo bzang chos kyi rgyal mtshan) after tutoring the Fourth Dalai Lama (Ta la'i bla ma) Yonten Gyaco (yon tan rgya mtsho) in the $17^{\text {th }}$ century. ${ }^{1}$ However, the spiritual tradition of Panchen Lamas goes back to the 15th century, to one of the direct disciples of Tshongkhapa Lobzang Drakpa (tsong kha pa blo bzang grags pa), who was a founder of the Gelug (dge lugs) sect of Tibetan Buddhism. His name was Khedrub Gelek Pelzang ( $m k$ has grub dge legs dpal bzang), and he was given the posthumous title of first Panchen Lama. Then the spiritual tradition as a continuation of subsequent reincarnations of Panchen Lamas occurred in Tibet (bod) for six centuries, up to the XX century. Starting from the aforementioned Lobsang Chokeyi Gyaltsen, who is recognized as the Forth Panchen Lama, the tradition was assigned to Tashilhunpo (bkra shis lhun po) monastery near the town Shigatse ( $g$ zhis ka tse), which is located in the Tsang (gtsang) region of central Tibet. The monastery was founded by the first Dalai Lama, Gendun Drub (dge 'dun grub), in 1447.

Both traditions, the Dalai Lamas and Panchen Lamas were closely interrelated with each other. They belong to the same Gelug sect of Tibetan Buddhism, which had been ruling Tibet for three centuries up to the middle of XXth century. Both are high reincarnations: Buddha Amitabha in the case of Panchen Lamas and Bodhisattva (byang chub sems dpa') Avalokiteśvara (spyan ras gzigs), in the case of Dalai Lamas. They are interlinked by a special kind of spiritual relationship, which is considered as as that of father-son, or master-disciple. As for the institutions, they were supposed to support each other in the process of finding and choosing a proper child who then would be the next Panchen or Dalai Lama. Both of them were closely engaged in the process of education of the newly discovered successor of the deceased former Panchen or Dalai Lama. They took part in official ceremonies as the monastic vows were taken by the child or later, in the enthronement on their respective religious position.

${ }^{1}$ K. Dhondup, The Water Horse and Other Years, p. 10. The title "Panchen Pokto" was bestowed on Lobsang Chokeyi Gyaltsen by Gushri Khan in 1645 and the title "Panchen Erdeni" was

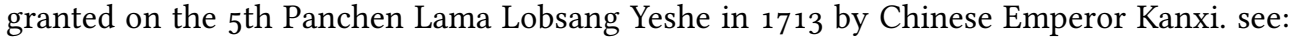
Y. Hanzhang, Biographies of the Tibetan Spiritual Leaders, p. 1. 
However, their strong spiritual relationships were often undermined by politics. During the course of Tibetan history, Tashilhunpo, sometimes pretended to be a second centre of political and economic power in Central Tibet, therefore being, in this way, a kind of competitor to the government in Lhasa. There were even some separatist tendencies in the Tashilhunpo administration, which were an obvious focus of interest for external forces such as British India and Qing's or Kuomitang's China.

\section{The tulku tradition}

The tradition of tulkus as an institution starts from the 13th century when it was established as an approved system of passing on religious authority within the Karma Kagyu ( karma bka'brgyud) school of Tibetan Buddhism. It is said that the first recognized tulku of Tibet was Karma Pakshi (karma pak shi) who was acknowledged as a reincarnation of the 1st Karmapa, Dusum Khyenpa (dus gsum mkhyen pa), or the 3rd Karmapa, Rangyung Dorje (rang byung $r$ do rje), who was a successor of the same Karma Pakshi. ${ }^{2}$ Then, this system was adopted by other sects of Tibetan Buddhism and Bon (bon); however, some of the sects followed different ways of choosing their spiritual and temporal leaders as in the case of Sakya (sa skya) school and partly in Nyingma (rnying $\mathrm{ma}$ ). In the 16th century, systems of tulkus were also approved by the Gelug school of Tibetan Buddhism, which was growing in strength at that time.

Since the tulku system is a distinct feature of Tibetan Buddhism and doesn't occur in such a form in other branches of Buddhism in Asia, it needed some doctrinal grounds to justify its own existence. There are a few main characteristics of the doctrine system of Tibetan tulkus, which can be pointed out as the basis of its development and final establishment as a cultural and political institution. ${ }^{3}$ First of all, the doctrine of tulku is based on the indisputable assumption, assumed by the majority of Buddhists, that reincarnation exists. Furthermore, the law of karma is accepted as a force which subjugates all living beings to endless circulation in Sansara ('khor ba). However, the one main distinction which distinguish tulkus from ordinary people is that tulkus gained an ability to control karmic forces during the process of transmigration from one life to another. Simply speaking, they appear in

2 D. Berounsky, Entereing dead bodies and the miraculous power of the Kings: The landmark of Karma Pakshi's reincarnation in Tibet, pp. 7-33.

3 See: R. A. Ray, Some aspects of the Tulku Tradition, pp. 35-7o. 
this world out of compassion for others to help them to liberate themselves from the yoke of mundane existence. Since it is the aim of Bodhisattvas of Mahayana, tulkus also represent this attitude towards other sentient beings.

Another feature of Mahayanist impact on the doctrine of tulku is the concept of Trikaya (sku gsum), the three bodies of Buddha. Tulkus are considered to be nirmanakaya ( $s p r u l s k u$ ), a manifested body of the Buddha; however, Tibetans refuse the Chinese term "Living Buddhas", applied sometimes in literature to their high tulkus. Tulkus are manifestations of Buddha or Bodhisattva rather than an embodiment of deity; however, this distinction doesn't seem to be very clear. Apart from this, there are many types of tulkus and only a few of them can be regarded as such unusual beings who are linked to the Buddhist pantheon of Buddhas and deities. Most tulkus are "ordinary" tulkus, which means that they are reincarnations of deceased lamas or other spiritually accomplished masters.

As the institution of tulku took root in Tibetan Buddhism and has existed as a part of the religious and social system for more than seven centuries it has evolved into a sophisticated and complex doctrine which cannot be described in detail in this paper. ${ }^{4}$

\section{Research in Dharamsala}

The research which I undertook in India is focused on one aspect of the issue of tulku. In Tibetan society, tulkus, through the centuries of existence of their tradition, enjoyed a special position. Broadly speaking, tulkus were considered "unusual", the kind of beings who, by the fact of only being recognized as such, deserved special treatment and reverence from other members of the society. As genuine Bodhisattvas, they have been presented as having extraordinary capacities of mind, such as, for example, an ability to learn quicker than others, especially with regard to acknowledging the secrets of Buddhist doctrine. Apart from that, the majority of them benefited from a privileged economic position within society by being the heirs and administrators of monastic manors called labrangs (bla brang). Those facts placed them in the position of local feudal barons, who sometimes executed their rights to govern their properties in an almost unrestricted way. Of course, this varied according to different circumstances, but, in general, their social position was undoubtedly unusual in Tibetan society, even if their economic

4 See, for example: D. Barlocher, Testimonies of Tibetan Tulkus, or, E. Asshauer, Tulkus - The Mystery of the Living Buddhas. 
position was not taken into account. In brief, tulkus were miraculous beings, who deserved adoration and estimation merely for coming into this world.

On the other hand, such veneration towards the tulku from the side of ordinary people did not prevent attempts to manipulate the process of recognition of a particular tulku by their respective families. To give an example, when a searching committee reached a particular area, where it was expected that the tulku of a particular master could be found, the parents would try to present their children as those who bore special capabilities which might indicate their tulku status. The reason for such activities of the parents was linked to the expected social and material profits which would flow from the recognition of their child.

The aim of my research on Tibetan tulkus is to answer the question about how the tulkus are now perceived by the Tibetans who live in exile in India. After the change in the political situation in the 1950s, when Tibet became part of China, more than a hundred thousand Tibetans ${ }^{5}$ emigrated to India and Nepal, following the Dalai Lama and other high lamas of Tibetan Buddhism. The majority of them settled in India, living in separate communities dispersed throughout the country. This situation has had an unquestionable impact on Tibetan culture, in general, by the fact that the exiled community, in comparison with the rest of Tibetans who live in China, live in entirely different conditions.

Living abroad has influenced many aspects of the life of Tibetans living in exile, who are now faced with a different, Indian, cultural environment. Before the 1950s, Tibet had been a quite isolated land, with a distinct culture, which had sustained the social structure throughout the centuries. It can reasonably be stated that this culture had remained almost intact there. The system of reincarnated lamas was undoubtedly one of its main components, and different levels of society benefited from it. As it was designed to protect the material position of the monasteries and religious sects of Tibetan Buddhism in their competition with the aristocracy, it therefore benefited mainly the Buddhist clergy. Furthermore, the system of tulkus acted as a means of social control, with its prolific rites and paths of social conduct, which guaranteed the sustainment of the societal status quo. However, it would be an oversimplification to say that the system of tulku served only as an instrument of exercising social authority by the hierarchy of Tibetan Buddhism. In the case of the institution of tulku, it is not easy to discriminate its different levels of impact on Tibetan society and culture. Undoubtedly, it

5 Indo-Tibetan Relations: Shared Heritage Shared Future, p. 69. 
sanctified the social structure by ascribing to it a divine element of emanation of the Buddha or some great Bodhisattvas. Some of my interlocutors, during the interviews, didn't hesitate to describe the tulkus even as a kind of god or as deities and, for them, there was not contradiction between this and the atheistic assumption which lies as a base of Buddhism. However, this is not so surprising, if we take into consideration the number of gods, semi-gods and deities inhabiting the levels of Buddhist worlds. Nevertheless, tulkus were a type of manifestation of those supreme beings, serving as proof of the uniqueness of the doctrine of Tibetan Buddhism and, in consequence, the uniqueness of the Tibetans, both in a more general sense, as a nation-if we consider the status of the Dalai Lama who is its ruler-and in more local sense, where monasteries sanctified their feudal rights by emphasizing the special religious position of their tulkus in particular communities. Nevertheless, I can make a reasonable assumption that tulkus served in "old Tibet" as a mean of creating cultural identity, both in a local and national sense. This is clearly seen in the policy applied by the fifth Dalai Lama, who, during his reign, was consequently promoting the idea of being the emanation of bodhisattva Avalokiteśvara within Tibetans, by organizing public religious rituals related to his unique status. ${ }^{6}$ Furthermore, as has already been mentioned, the tulku system was sometimes a means of changing social status not only for a particular child, who was recognized as a reincarnation, but for the whole family of this child, since, in rare cases, high tulkus were picked from poor families. In the 19th century, some Dalai Lamas were recognized in poor families living outside the U-Tsang (dbus - gtsang) region. The reason for this was twofold: the hierarchy of the Central region of Tibet, in an attempt to avoid the quarrels concerned with finding reincarnations, decided to search for them in areas placed outside their direct authority. ${ }^{7}$ Furthermore, as the families of the newly found Dalai Lamas were then elevated in their social status, by choosing the child in such families who had not lived in their manors, they avoided upsetting the existing social hierarchy. ${ }^{8}$

6 Y. Ishihama, On the dissemination of the belief in the Dalai Lama as the manifestation of the Bodhisattva Avalokiteśvara, p. 538-552.

7 M. T. Kapstein, The Tibetans, p. 161.

${ }^{8}$ It was also a consequence of the impact of the state regulations promulagated by Qing Emperor, Qianlong in 1793. with regard to the process of recognizing tulku in Tibet and Mongolia. According to this law which implemented the obligatory use of so-called "Golden Urn" during the recognition of the tulku of particular lineage, reincarnations of the high lamas should be found outside of the noble families. See M. Oldtmann, Forging the Golden Urn. 
Such cultural conditions, described briefly above, vanished with the changing of the political situation in Tibet. Many tulkus, following the decision of Dalai Lama, emigrated to India and then to the "West". Due to these circumstances, the Tibetan religion experienced the outside world and had started to be exposed to its impact. The same occurred with the Tibetans in exile, who were no longer separated from the outer world by the ranges of Himalayas. Almost sixty years have passed since the first Tibetans refugees found their way to their freedom in exile. During this time, the religious institutions of Tibetan Buddhism have settled in different countries around the globe. In India, the main Tibetan monasteries, which served in "old Tibet" as centres of religious and political activity, were duplicated. A great many Dharma and Retreat Centers were established, where Tibetans have an opportunity to meet Western followers of Buddhism. Those new believers have brought with them their Western mentality and a different approach to following the Buddhist religion. Tibetan lamas, supported by Western Buddhists, went to Europe and America to build Buddhist communities there, trying, at the same time, to accommodate the ancient system of philosophy and faith to modern culture. In recent decades, the globalization of culture also found its way within Indian society, shaping the mentality of a new generation of Indians and Tibetans youths as well. Such facts, which are only a few of many relating to the topic under discussion, must have left their imprint on the institution of the tulku in exile.

It is important, however, to be aware of the fact, that the tulku institution continues to exist in the Buddhism practised by Tibetans currently living in China. Nevertheless, this topic is beyond the scope of my present research; therefore, it won't be discussed in detail in this paper. Generally speaking, the Chinese state is going to take full control over the tulku institution by implementing a policy which leaves the political and legal instruments which make it effective to the state officials. ${ }^{9}$ The most well-known example of this policy is, as discussed in the interview, the controversy over the double choosing of Panchen Lamas. Gendun Choekyi Nyima (dge 'dun chos kyi nyi $m a$ ), recognized and supported by the Dalai Lama, the TGIE (the Tibetan Goverment in Exile) and the mass of followers of Tibetan Buddhism, and Gyaltsen Norbu, (rgyal mtshan nor bu), elected by Chinese officials. This issue, after more than the two decades since a boy recognized by the Dalai Lama, disappeared together with his family, whose whereabouts are officially un-

9 M. Slobodnik, A Difficult Rebirth: Tibetan Reincarnations in the Spotlight of Chinses Religious Policy, p. 57-80. 
known, is still the focus of interest of international campaigns and activities of Tibetan organizations in exile.

To summarize what had been said up to this point, I have been reasonably convinced that the perception of the institution of tulku within Tibetan society in exile has changed in recent decades, in comparison with what had been thought regarding that subject earlier. However, this assumption is not going to be proven by my research, which is restricted to presenting the understanding of the institution of tulku by Tibetans living in exile. I presume that such comparative research on how the perception on tulkus has changed within Tibetan society over the previous century would be a valuable contribution not only to Tibetology, but also to religious studies in its broad context.

\section{The idea of the interview and applied methodology}

Geshe Lhakdor is a director of LTWA, where I made my source enquiry. He is one of the close assistants of the Dalai Lama and was also his translator. Having an opportunity to meet him in the library in Gamru, near Mcleod Ganj, I asked him about the possibility of making an interview on Tibetan tulkus. He agreed with my request; however, due to his tight schedule, he proposed it be made after a month or so. As was said during an informal short talk somewhere on the corridors of LTWA, I wasn't quite sure whether Geshe would remember our conversation. However, fortunately for me, I met him a few weeks later and I asked him about our planned interview. Then, he immediately agreed to make an interview on the same day, two hours later, in the morning. As I carried printed versions of the interview with me in those days, I decided to give him a copy of it and also a printed version of a summary of the aim of my research. Therefore, he knew the structure of the interview, with its eight questions, before our meeting. Below, I present all those questions in the same order as they were passed on to my interlocutor.

\section{Questions for the interview (short version)}

1. Who are the tulkus?

2. What was the role of tulkus in "old Tibet"? What is the role of tulkus in contemporary Tibetan society, both in China and in exile? 
3. How has the controversy with choosing "double" tulkus influenced the credibility of the tulku institution?

4. What was the position of Panchen Lama in Tibetan Buddhism in Tibet?

5. How should Tibetan Budddhists act towards the Gyaltsen Norbu supported by Chinese authorities?

6. Is there any possibility of controlling the tulkus with regard to their strictness in leading the life of a Buddhist teacher?

7. How should the issue of fallen tulkus be dealt with? Those men disrobed themselves after many years of staying in monasteries, where they had been educated, since early childhood, according to the traditional Buddhist curriculum. After leaving monastery, they face a problem of living in lay society.

8. Is there any place for female tulkus in Tibetan Buddhism?

I have to mention, that, by informing my interlocutor about the questions before giving him an interview, I made a very rare exemption in my practice of conducting interviews. I did it this time, because I thought it would be better to give an opportunity to the interviewee to get to know my intentions with regard to the topic, which otherwise might be too sensitive to discuss. I took into the consideration the position of the Geshe Lhakdor in Buddhist hierarchy, his knowledge of internal issues of the Gelugpa sect and his responsibility for the exiled Tibetan community in Dharamsala. Therefore, I tried deliberately to overcome his reluctance to talk more openly during the conversation. I imagined that otherwise he might consider me as a kind of journalist, who was stirring up controversy.

I am quite convinced that my tactic succeeded in this case. By acknowledging, before the conducting an interview, that, for my interlocutor, I was still a rather anonymous and unpredictable person, who wanted to speak about important political issues for the Tibetans, I chose to show my hand. I think that at least I calmed my interlocutor with regard to my intention, and this allowed him to speak more openly. On the other hand, the kind and generous personality of Geshe Lhakdor, his sense of humor and compassionate wisdom, contributed to the limited success of our conversation. Instead of eight questions, I asked more than forty. I have the impression that, during this interview, some fundamental issues with regard to the topic of tulkus were discussed.

Those eight questions were extracted from the previously prepared questionnaire which I have called "The plan of the interview. The long version" with its forty-four questions. It is comprised of six parts. Part One is related to 
the personal data of the interlocutor, mainly to his involvement in Buddhist practice. As Geshe Lhakdor is a well-known Buddhist lama, I decided to skip this part of the interview. Then, the second segment of the "plan" consists of questions related to the doctrine and knowledge of the history of the tulku institution. Questions number 1, 4 and partly 2 belong to such a category. In the third segment, there are questions which pertain to the institution of tulku, investigated in the light of the modern culture. Questions 2, 3 and 7 partly relate to this area of interest. By responding to the questions assigned to the forth segment, the perception of the particular interlocutor on the issue of tulkus is investigated in a political context. Therefore, assessments are expressed which are directly related to the "positive" and "negative" sides of the topics discussed in questions 2, 4 and 5. Furthermore, questions 3, 5, 7 and 8 relate to the future of the institution of tulkus.

The questions generating the sixth segment relate to the opinion of the interlocutor regarding the questionnaire as a whole, and these were not included in the plan presented to Geshe Lhakdor.

The questions contained in the four segments mentioned above are directly related to the topic of the institution of tulku. However, during the conversation with Geshe Lhakdor, the subject of reincarnation, taken out of its Tibetan context, was also discussed. Therefore, the last part of the interview, almost completely revolves around such subjects as the Buddhist doctrine of reincarnation and modern science, the concept of mind and the quest for remembering past lives by particular individuals.

The aim of conducting fieldwork in Dharamsala is to answer the question concerning ways of perceiving the tulku institution by Tibetans living in exile. To accomplish such a goal, I have asked for an interview with many Tibetans, most of whom I recruited from the clients of one of the local NGOs in which I used to do a voluntary job. The other source of informants came from LTWA, where I had an opportunity to speak to the members of the staff or to Tibetan students conducting their studies. Most of my interlocutors didn't belong to the high hierarchy of Tibetan Buddhism, or they were not even monks; they were just lay people who consider themselves to be followers of Buddhism. Of course, it was much easier for me to speak to lay Tibetans and ask them to have an interview by inviting them for tea at one of the many Mcleod Ganj cafés, than make an appointment with some high lamas. However, I have thought that to gain a comprehensive picture of the investigated subject, I should to talk to people representing various social backgrounds 
within the Tibetan community. As I am still in the process of conducting my research, I would say that, for the moment, I only partly achieved this goal. To have a real cross-section of the Tibetan community in exile, I need to conduct more interviews, mainly with people who came from Tibetan Middle Class. However, the interview with Geshe Lhakdor, who is a high lama of Tibetan Buddhism, added an important voice to my survey, representing a particular social strata of Tibetan. Even considering the obvious fact, that this voice cannot be assumed as being representative of all Tibetan lamas, it can still be compared with similar opinions of other lamas. There is a literature in which, at least part of the thesis on tulkus expressed by different lamas, agrees with the opinions presented by Geshe Lhakdor. ${ }^{10}$

\section{The interview with Geshe Lhakdor}

MW. My first question is very general. Who are the tulkus?

GL. Tulkus are those who come back to this earth intentionally. Not because of the negative karma of afflictive emotions, but out of choice due to compassion, with the aim of serving others. Therefore, they are called tulkus or reincarnations. It is different from rebirth, because every person will be reborn. Therefore, reincarnation or tulku relates to a person who voluntarily came back because of wisdom and compassion.

MW. What is then the difference between high accomplished lamas and tulkus?

GL. Some tulkus are lamas, there is no contradiction between the two. Then, considering tulkus, there are many levels of development of tulkus. Among them, there are some who study, some who have attained a high level of realization. It is difficult to say who is who.

MW. Tulkus then come back to this world, as you said due to their karma...

GL. Not negative karma but positive karma. Ordinary people come back to this world not because of their choice but because of the force of the contaminated karma and afflictive emotions. The tulkus come back through choice. Suppose, I said, because of the fact that not ne-

${ }^{10}$ The more comprehensive source would be already mentioned: D. Barlocher, op. cit., or E. Asshauer, op. cit. Critical view on institution of tulku is presented in: Serta Tsultrim, The Glowing Legacy, pp. 127-128, Dzongsar Jamyang Khyentse Rinpoche, Time for Radical Change in How We Rise Our Tulkus, [www 01]. 
cessarily everybody who says that he is a tulku would be a real tulku. Our society is like any other society in which you can find a real practice and, at the same time, false practice.

MW. Geshe, you said "the real tulkus"?

GL. Yes. If you are the real tulku, it is like in this definition of the tulkus which I have already expressed. However, you have false tulkus...

MW. How is this possible?

GL. You have false tulkus, you also have false lamas. Some families arrange the recognition of their children because they expect some profit from it. This can also happen, and we should be aware of that fact.

MW. How many tulkus are there in Tibetan Buddhism now?

GL. I have no idea. So many.

MW. Are they in all five main Buddhist schools?

GL. Yes, they are.

MW. Do you know what the origin of the tulku tradition was?

GL. It started from Karmapas. The female reincarnation started from Samding Dorje Phagmo (bsam sdings rdo rje phag mo), but I don't remember the details. There are also some books on this written in Tibetan and also in English. You can find them in our library.

MW. What was the role of the tulkus in "old Tibet"? What is the role of the tulkus in contemporary Tibetan society, both in China and in Exile?

GL. It doesn't matter whether we talk about "old Tibet" or "new Tibet". Tulkus were always the spiritual teachers who, as I said earlier, come back to serve human beings or to all sentient beings. Therefore, whether it occurred in "old Tibet" or "new Tibet", the purpose is the same: to help all sentient beings who experience suffering. They have special possibilities because of the fact that they are tulkus and not ordinary monks. People then pay special respect to them and due to this, they have special responsibility to bring harmony, peace and happiness to all sentient beings.

MW. We know from the history of Tibet that tulkus also had a special, privileged position in society. For example, they inherited labrangs... and now, there are tulkus in China, in exile, in Europe, America. Does it make difference, where they live, how they pursue their aims?

GL. No, as I said before. If you are the genuine tulku, it doesn't matter whether you live in China, Europe or America. But the problem is 
that tulkus are chosen by people. Therefore, China chooses tulkus for political purposes. In the West, or even within Tibetan society, some of them might be not be genuine. For the purpose of gaining property or for other of those kinds of reasons, they manage to be called tulkus. This is wrong, of course.

MW. It is hard to avoid such things in such a big religious system, as in the case of Tibetan Buddhism. However, to prevent it, they should be chosen in the proper way. Who should recognize tulkus?

GL. It is not fixed. Each of the schools of Tibetan Buddhism has its own head lama. Therefore, they choose, or sometimes the other high lamas who belong to the particular school choose the tulkus. Sometimes, there are cases when nobody recognizes a person who then claim to be the tulku, and the people start to follow him. Therefore, there are a lot of problems connected to this. Who recognizes them and so on. In today's society, if you call yourself tulku and then go out, there will be a number of people who will follow you.

MW. In regard to that, what do you think of the traditional way of recognizing the child by presenting him with the objects which belonged to his predecessor?

GL. In the case of the process of recognizing the right tulkus, you are supposed to do a lot of experiments, such as, for example, the one which you mentioned. The others include going to different places, checking whether the child remembers his past lives. In some cases, it is easy to prove that the child is a real tulku because the boy remembers his past lives. He says, for example: "my teacher is here, my old room is here", and so on. In such cases, it is easy to recognize the tulku. Unfortunately, in other cases people tell lies about their children by claiming that they remember their previous lives, and there is no way to stop such behaviour.

MW. In Tibetan tradition there are so called "blessed tulkus". This means that they weren't recognized as incarnations of deceased lamas, but rather they were blessed by some high lamas and chosen as inheritors of a particular tradition. Therefore, the question is whether the institution of tulku can be considered as a kind of institutional way of help given to gifted children. In other words, giving them a chance to be educated and having a brighter future?

GL. Of course, as I told you. The tulku system was a spiritual thing which should provide help to gifted children if they were recognized in the 
proper way. Otherwise, if they were not selected properly, they can easily be corrupted.

MW. Geshe, to sum up your opinion on the tulkus. Do you consider them as children with special capacities?

GL. There is such a possibility. However, I don't have much hope with the tulkus. What do I like is when I see people who really study; therefore, they are educated and disciplined. This is important. Tulkus, as His Holiness said, is now like social status. The value of the tulku depends on the value of a particular person. However, the person who has studied, who has practised the teachings properly; this person is really useful.

MW. How should tulkus be trained? According to the traditional curriculum or according to Western science?

GL. The most important thing is that tulkus are not reincarnations of scientists. They are reincarnations of Buddhist teachers; therefore, naturally, their job is to maintain Buddhist traditions. This is most important. Then, as their aim is to help others, it is beneficial for them to have some knowledge of modern science and Western education. However, as I said before, this is not the most important thing.

MW. Is this the same in the case of "Western tulkus"?

GL. Yes, of course. The Western tulkus should be reincarnations of Tibetan or Buddhist masters. Therefore, the purpose of the Buddhist teacher is to continue the Buddhist tradition, not the scientific one. For them, the most important thing is Buddhist study and practice.

MW. Is it correct to say that tulkus are not considered as teachers for lay people?

GL. Tulkus are not just for monks, of course not. They are for everybody.

MW. Geshe, you have just distinguished very sharply between the lay and religious type of education.

GL. This is a different thing, and it has nothing to do with the tulkus. There is monastic education and lay education, both of which are important. However, monastic education is like a specialization. You focus on studying Dharma; therefore, it is similar to going to college or university to study a particular subject.

MW. However, His Holiness the Dalai Lama welcomes the dialogue between Buddhism and science by organizing, for example, the meetings of the Mind \& Life Institute. 
GL. GL. His Holiness supports these programmes not for the reason that science is the most important thing. For us, I mean, for Buddhists, the most important thing is Buddhist teaching. However, if you teach others, it is useful to have modern, scientific knowledge. Furthermore, if you have both a scientific and Buddhist perspective on a particular topic, it deepens your inner-self and its realization. However, we are not doing this because we think that science is more important than Buddhism. It is not like that. Science is only for that life. It has nothing to do with spiritual development; it is only focused on the material side of life. They are totally different, but regardless of that, we still can learn from the science. Simply for the reason, that many of its findings are useful.

MW. This is why tulkus are not prepared to teach people modern science?

GL. They can study science, but this is not so important. The most important thing is to preserve the Buddhist tradition.

MW. Does this mean that they should cling to only one particular lineage of Tibetan Buddhism?

GL. Not necessarily. It is good if you develop a non-sectarian attitude. Suppose that you are English teacher. You can also study mathematics. It is useful, you can also study science; however, your main field of knowledge is the English language. Similarly, Gelugpa has its own curriculum, but if you also study from others, it is useful for us.

MW. Let's change the subject and talk about some controversies connected with the tulku institution. Has the issue of choosing the "double tulkus" influenced its credibility?

GL. Not necessarily. Because this was created by people and people sometimes do some stupid things. Basically, they can be the five reincarnations of the one person. The reincarnation of the body, speech, mind, quality. Cig, nyi, sum, shee - yes and sublime activity, the fifth. This is not so in every case, but it is possible. Nevertheless, in the cases where people ask who the right tulku is, then the problem arises. You do not then consider those tulkus as emanations of the body, speech and mind, but instead of that you say: "I am the only reincarnation of the Karmapa. One is the real and the other is false." Then, there is a problem. This is politics. Then, it is difficult to say who is right and who is wrong, because if you don't have a firm belief in those spiritual things, how will you decide? Some people believe in this 
Karmapa, some of them believe in the second. Many of these beliefs are based on blind faith. Faith mixed with blind faith. The reason for that situation is unhealthy competition. This is why I am not so interested in those kinds of things.

MW. As you, Geshe, said: "there can be five reincarnations of the one person." There is even a possibility that a master who is still alive can have some reincarnations. Those reincarnations are called "made tulku" in Tibetan Buddhism ( $m a$ 'das sprul sku).

GL. Yes, we called them "made tulku", not in the sense that somebody who has already died has then been reincarnated, but in the sense that somebody continues the function of this person in society. This is why that person is selected before that other person dies, because he is going to proceed with the work of the person who will die. This is the meaning of the term "made tulku". The person who is selected as a "reincarnation" of the person before his death.

MW. Therefore, it should be understood as a continuation of a particular tradition?

GL. As I said before. It depends how pure your intention is. In the past, the really great teachers were able to foresee the future; I mean the really great teachers, not the fake ones. Some of them decided: "my reincarnation would be useful", or "this person is really going to be my reincarnation, he practises Dharma, he is respected by others", whatever... Therefore, it is a big advantage to point out such a person. According to this, in such a case, it is not necessary, that the person is a real reincarnation. Then, he is given a title, which is useful if it is a pure spiritual thing. Unfortunately, when it is used for particular purpose, it started to be corrupted.

MW. The idea came to my mind that the person who recognizes the reincarnation should be a good psychologist so as to predict the future of the particular child.

GL. Let's say that somebody can predict the future of the child. This can also happen. Nonetheless, in most cases we can predict the future of a particular person by looking back into their personal history. If somebody is reliable for twenty years, it is very likely that he would be still reliable in the future. We can't really predict what a particular person is going to do in the future, but we can responsibly say whether this person is good or bad based on his past life's experiences. 
MW. To change a subject, I would like to ask you, Geshe, about the position of Panchen Lama in the "old Tibet". What was his role in Tibetan Buddhism?

GL. We have already discussed this issue. The Chinese recognized the fake Panchen Lama for political purposes. This is related not only to the Panchen Lama, but also to many other lamas who were recognized by the government. This has nothing to do with religion, and it is purely for political purposes. The Communist Party, which calls religion "a poison", recognizes the reincarnations of Tibetan lamas, at the same time not believing in their reincarnation. How can they choose? Now, they want to choose the reincarnation of His Holiness Dalai Lama: this is for political reasons, as a way of controlling society. People still have a lot of faith in the lamas; therefore, they want to control them. Actually, what they really need to do is to slowly destroy everything. The authorities started to recognize lamas as a means of entrapping people.

MW. Do you think this is a deliberately created plan to erase Tibetan Buddhism?

GL. Of course, this what I think. They clearly stated that there are two things which must to be destroyed to create harmony between the Tibetans and Chinese. Those two things are the Dalai Lama and Buddhism. They compare the Dalai Lama with the head of the snake. "If the head of the snake is cut"... they said this... This is related not only to Buddhism. Christianity-any religion which becomes powerful-is a threat to the authorities. That's why a lot of big monasteries, including the Serta La Rung (gser thar bla rung), have been destroyed. Some churches have been destroyed. Any party which grows in power is considered by the authorities as a threat; therefore, they try to weaken it. They need only one party in China.

MW. The Panchen Lama is one of the highest lamas in the Gelugpa school of Tibetan Buddhism. Can you explain his position within Tibetan Buddhism?

GL. His relationship with the Dalai Lama has been described as that of "disciple to teacher". Generally speaking, I don't know what the opinion of other schools of Tibetan Buddhism is in regard to this subject, but, for the people, the Panchen Lama was the second highest reincarnation after the Dalai Lama. However, as I said, I don't know whether all the schools of Tibetan Buddhism would agree with this. 
MW. Therefore, do you think that position of the Panchen Lama has declined due to the fact that Gyaltsen Norbu was recognized by the Chinese authorities?

GL. It's not like that. Gendun Chokeyi Nyima, who was recognized as the 11th Panchen Lama by His Holiness, according to his words, is still alive and studying somewhere. This Panchen Lama is in the hearts of almost all Tibetans. The other one is the Chinese puppet. What is he doing is show business. He is helpless. Nevertheless, he is not the only one who is controlled by the Chinese government. Millions of people in China have to do whatever the communist regime tells them.

MW. How should ordinary Tibetans react to the activities of Gyaltsen Norbu?

GL. This has been very clearly stated. The Panchen Lama recognized by the Dalai Lama is the correct one, but in Tibet people are not even allowed to say something like that. Let's say, there is an example with the ceremony of Kalacakra (dus kyi 'khor lo), which was given by the "Chinese Panchen Lama". People simply didn't come to attend the event, so then they were forcibly gathered by the authorities. This is the reality.

MW. This is an example of how politics uses religion.

GL. Bad people uses not only religion in that way. Corruption, illegal things, killing, silencing people... everywhere in the world is like that.

MW. According to the historical sources, religion was also a part of the politics in Tibet. Buddhism was, as a matter of fact, the state religion. Ganden Phodrang ( $d G a$ ' ldan pho brang) was a religious government, which operated for three centuries.

GL. This is what His Holiness calls "an unhealthy situation”. This is why he resigned from his power by passing it on to the lay government. He doesn't want to continue this tradition of the Dalai Lamas ruling Tibet. He also said that, in fact, he would be happy to put an end to this practice; I mean, to separate religion from politics. Politics is a means to bring about divisions, due to the fact that there are several parties. On the other hand, in my opinion, spirituality shouldn't be divided. Religious practices might be the source of divisions, but this is not genuine spirituality.

MW. What about tulkus? There are sometimes problems with them... 
GL. There are a lot of problems in this world, not only with tulkus. This is sansara - problems with men, problems with women, with the environment - it is not surprising at all. So long as we live with other human beings, there will be some problems.

MW. However, is there any possibility to control the behaviour of the tulkus?

GL. The possibility is always there. You can become a Buddha. There is such a possibility. Can you become a Buddha? It is very difficult.

MW. It is said that this is the aim of the practice.

GL. Yes, this is the aim, but it is not easy to achieve. Therefore, with regard to your question, the important thing is to recognize a real tulku. Then, to give to this selected child a good education. Make him a good human being. As they are special, they should already be a good human being, but this is not the case. Not every tulku would necessarily be a good person. In such cases, it is clear that they were wrongly chosen or that there is something wrong. At least, what can be done is to give tulkus a good education and to do everything to make them a good person.

MW. How can tulkus be trained?

GL. In the same way as other people.

MW. However, the traditional system of Tibetan education could be very harsh for children, since it included physical punishment.

GL. This is what can be changed. Every system of education has its good and bad points, and if there is something like beating children it must be stopped. We can change these things, this is not a problem. Nevertheless, even considering this, it doesn't mean that we are completely apart from modern education. Modern education also has its own shortcomings. Let's look at the people educated in the modern, Western way. You don't find many of them to be compassionate human beings. They are selfish and egoistic; therefore, this system also needs some improvements and advice taken from the Eastern or Buddhist tradition. In the matter of the system of education, we should use our common sense and remain open-minded, to adapt what is best in both of those traditions.

MW. How is it possible to cope with the issue of so-called "fallen tulkus"? We can meet some of them in Dharamsala. Those men disrobed themselves after many years of staying in monasteries, where they had been educated since their early childhood according to the traditional 
Buddhists curriculum. After leaving the monastery, they face the problem of living in lay society.

GL. This is their mistake. Therefore, they have to suffer the consequences of their wrong choice. It is the same as in the case of any other human being. If you are disrobed - actually, I believe that a genuine tulku can't fall. If you are a genuine reincarnation, let's say a monk, then, even if he disrobes-for example, he met a beautiful woman - then, he is no longer a monk, but he is still a tulku. It is not possible to fall from the position of tulku.

MW. Like Cangyang Gyatso (tshangs dbyangs rgya mtsho). ${ }^{11}$

GL. Whoever, he is still a tulku. This cannot be changed. However, even when he keeps the title, after leaving the monastery, he can't do the same things which he used to do in the monastery. In my opinion, this shouldn't be a big problem. A Tulku who is no longer a monk should live as other people. You shouldn't pretend that you are very special. That person should find a job, study hard and live as other people do. However, there are some cases, when a tulku who was disrobed still behaves as if he were a special human being. Wearing yellow clothes and so on. Personally speaking, I don't much like such people. Those people want to take the best of the both worlds.

MW. You mean that they should be consistent with themselves?

GL. Absolutely. Otherwise, you are neither good as a monk nor as a lay person. Therefore, who are you? There may be some exceptions from this, but, generally speaking, this is my opinion on this subject. It is then his business, how he deals with his life.

MW. What about the position of women in Tibetan Buddhism? Is there any place for female tulkus in Tibetan Buddhism?

GL. Yes, of course. Samding Dorje Phagmo, the first woman reincarnation, who came at the time of the first Karmapas. Therefore, the system of tulku is also for women, there is no restriction with regard to this.

MW. Ven. Geshe, what will be the future of the institution of tulku?

GL. I am not too worried about that. I think that it will continue, due to the fact that the blind faith of the people will never go away. Blind faith or to use a better expression: faith. There will always be enough people who believe in a particular reincarnation. Therefore, there is an opportunity for them to come. Good as well as bad. Good, because

${ }^{11}$ The Sixth Dalai Lama. 
of their faith. They can serve, they can help; therefore, the right reincarnations can come. False reincarnations can also come, because it is a market. This is possible because of the people-superstitious, not educated-who always rely on others, depend on others... Ordinary people always have this kind of mentality which is based on relying on others, looking to be guided by others. This kind of herd mentality. They don't have knowledge, the kind of foresight to think and decide for themselves. They always want to be led by somebody. This is why the fake leaders come and they can survive. As I said, it is a market.

MW. How can tulkus can contribute to the modern society?

GL. The purpose of the tulku is to help all sentient beings, not only the Tibetan people. However, if you are Tibetan, you have a special responsibility to Tibetan society, but, in general, their aim is to help all sentient beings. Because of the fact that they hold the title of the tulku, they have a special capacity to do so.

MW. Should the tulkus be regarded as a kind of NGO for the Tibetan community?

GL. No, it is not like that. Tulku is not an institution; it is always a particular person. Tulkus have their labrangs, this is true, and due to this fact, they can act as a kind of NGO. This depends on what they do. They can lead their individual projects and they can cooperate with institutions, whatever...

MW. His Holiness, the Dalai Lama used to say, that if scientists proved that reincarnation doesn't exist, he would simply accept this fact. What do you think, considering the fact that belief in reincarnation is a fundamental assumption of Tibetan Buddhism?

GL. No, not reincarnation. After and future lives. Tulkus are related to that. What he talked about relates to anybody: to you and me. In Buddhism, we believe that after you die, your mind continues to live and then rebirth will happen again. Sansara: dying and being born again, dying and being born again. If scientists were able to prove that there is no afterlife, he said that he would believe this. However, it is not easy to prove this.

MW. How is it possible to prove that reincarnation exists?

GL. How to prove this...? That the mind continues. There is an end with regard to the body, but it is not so with regard to the mind.

MW. Therefore, what is the mind? 
GL. The mind is very subtle energy. When you die, the grosser energy dies with the gross body. However, the subtle energy or the mind, can remain independent of the body, and then it will continue. That is the point of the whole discussion between Buddhism and science. Scientists say that it is nothing more than brain activity. Therefore, when somebody dies, his brain dies and this is the end of the story. There is no future life. Buddhism doesn't agree with this. According to Buddhism, there are grosser and subtler levels of mind. The grosser level of the mind depends on the body and brain. Due to this, when the grosser level body dies, and the brain dies, the grosser level of mind also comes to its end. However, the subtle level of the mind can continue independently. To give you an example. If you go to bed to sleep, you close your eyes, your ears can't hear anything. You snore, sleep and you are almost like a dead person, but your mind remains active, even more active. You have dreams. You dream that you are writing something, or shopping in Mcleod Ganj. When you are sleeping, your body is like that of a dead person, but you are laughing, because of the fact that you had a good dream of meeting some people or you have a nightmare and you are shouting. This shows that when the grosser level of mind withdraws, then the subtle level of mind becomes more active. But, a more powerful argument for the afterlife is the fact that some people simply remember their past reincarnations. During the process of death, everything is destroyed. Then, how it is possible that a child can remember his past life. There is no connection with the gross body. However, we have cases of people who do so-not one person but several thousand-this has been proven not only by Buddhists, but also by scientists. There is a scientific organization in New York, which has interviewed many people in a big project, who vividly remember their past lives.

MW. This is what I am interested in.

GL. Exactly. This is solid proof. And, in many reported cases, it is like that, that the memories from a past life are remembered at the age of three and four... also, there is more likelihood of remembering a past life if the death was a result of an accident. Therefore, there are several interesting cases, and these have been highlighted. For example, there is a case of a girl, who remembered that in her previous life, she had been shot. The bullet entered here, and came out here. She remembered the situation, but what is more convincing is that in this 
life the scar is here and here. In the same parts of the body where the bullet passed through. Therefore, there are not only mental traces of the things which happened in the previous life, but also physical ones which can be studied and linked to the past.

MW. How does the subtle mind remember the previous life?

GL. What?

MW. How does the subtle mind remember the previous life?

GL. How does the computer remember that which you have stored in its memory?

MW. There is data...

GL. Exactly, you stored it.

MW. I don't know...

GL. How does the computer remember data? Going deeper and deeper, you will find that it is just an imprint. It is an imprint. You are leaving imprints. ${ }^{12}$ You are recording what I am saying. How does this device record? Then, you are able to hear it again, how does it do that? Because there is capacity there, to retain and not to forget... you see... and you can play it again... the process is similar in our case.

MW. Therefore, Geshe, do you think that we pass all of our memory from one life to the next?

GL. Absolutely. This depends on your experiences. You don't remember everything, except those things which are striking or which you experience as fear or a great joy... those things you remember. Many other things, you don't remember. For example, you don't think about the years which have passed, only about this day. What did you do today? We do many different things during one day. You do not remember them and neither do you dream about all of those activities. However, you do dream about those which made the greatest impression on you.

MW. I still think that this is a matter of faith...

GL. Because, the whole problem is that we believe only in material things. Therefore, it is not easy for us to think about the mind which is nonmaterial. However, in Buddhism, we talk not only about mind as nonmaterial, we accept the whole non-material realm, called the formless realm, where human beings exist living without body. We, as people, are strong, having solid bodies, but let's look at the mosquito. How

\footnotetext{
${ }^{12}$ In Tibetan, karmic imprints are called bagchag (bag chags).
} 
can he sting being operated by his small mind? We can go even further, in the water which we drink, looking at it using our eyes, we would not see any living creature. However, by using a microscope we discover many small leaving beings. Therefore, you can go deeper and deeper into the most subtle levels where there is only pure energy. Viruses, bacteria, how do they function? Do they have a brain? I don't really know how big their brain is or whether they have one at all, but somehow they function.

MW. Therefore, how do you explain the functioning of the mind? How did the mind begin?

GL. This is like asking how trees began. Due to the presence of causes and conditions.

MW. Thank you very much, Venerable Geshe.

\section{Commentary on the interview}

As I mentioned before, the interview with Geshe Lhakdor contains four main segments of questions, with a fifth about reincarnation in the general sense added to it:

1. Doctrine and knowledge about tulku;

2. tulku in contemporary Tibetan communities;

3. the political context of the institution of tulku;

4. the future of the institution of tulku;

5. the concept of reincarnation.

Following this outline, I shall summarize opinions on each of those subjects, expressed by Geshe Lhakdor during our conversation:

\section{Ad 1: doctrine and knowledge about tulku}

During the interview several topics were discussed with regard to the doctrine of tulku. The key question was, of course, "Who are the tulkus"? The answer, which was given by Geshe Lhakdor, corresponds to the approved meaning of the concept of tulku: "Tulkus are persons who come back to this earth intentionally". This means that tulkus are those special beings who have gained control over their rebirths, following at the same time, 
the Mahayanic path of Boddhistavas. However, Geshe then added that: "The value of the tulku depends on the value of that particular person". This statement brings the concept of tulku down to earth. I would say that Geshe was presenting this kind of approach to the topics under discussion throughout the whole interview.

Then, other doctrinal issues with regard to the institution of tulku were mentioned, such as the conceptual differences between tulkus and lamas and the different types of tulkus which are present in Tibetan Buddhism: "made" tulkus and "blessed" tulkus. Here, again, this characteristic, twofold type of understanding of the phenomena of tulkus by Geshe Lhakdor appears. I said twofold, because, on the one hand he totally backs the doctrine of tulku, which is considered by the science of religion as "esoteric". A "made" tulku, according to Tibetans, can reincarnate during the life of their predecessor; furthermore, they can reincarnate in multiplied forms. Nevertheless, on the other hand, as Geshe said: "according to this, in such a case, it is not necessary that the person is a real reincarnation. Then, he is given a title, which is useful if it is a pure spiritual thing. Unfortunately, when it is used for particular purpose, it started to be corrupted". By saying this, Geshe underscored the possibility of a gap developing between religious theory and how this theory is sometimes applied to real life circumstances. He is even more straightforward with his criticism towards the institution of tulku, when he comments on so-called "false tulkus": "Some families arrange the recognition of their children because they expect some profit from it". However, the reader of those words would not have the impression that Geshe undermines the whole concept of the tulku, as it is presented in Tibetan Vajrayana. His Buddhist point of view is clearly stated in his opinion on the topic of how the tulkus should be recognized. Again, in this case we have a twofold approach, doctrinal and more pragmatic. Geshe Lhakdor, as a Tibetan Buddhist, believes in reincarnation; therefore, for him it is natural to claim that children are able to remember their past lives: "In some cases, is easy to prove that the child is a real tulku because the boy remembers his past lives". This statement is in total consistency with not only Tibetan understanding of reincarnation, but, broadly speaking, general Asian understanding of reincarnation. It happens that a particular person or child claims that he can remember their previous life, and most of such accounts come from Asian cultures. However, Geshe then acknowledges that not all of those accounts, at least in the case of tulkus in Tibetan society, are genuine cases of reincarnation: "Unfortunately, in other cases people tell lies about their children, 
by claiming that they remember their previous lives and there is no way to stop such behaviour". In other words, Geshe wants to make clear that, whilst seeing the shortcomings of the tulku system, he warrants its credibility as a system of spiritual knowledge, based on the assumption of the existing phenomenon of reincarnation.

\section{Ad 2: the tulku in contemporary Tibetan communities}

This twofold approach also seems to pertain to the statements of Geshe Lhakdor which relate to the position of tulku in the modern Tibetan community. Answering this question, Geshe says: "Tulkus were always spiritual teachers who, as I said earlier, are believed to come back to serve human beings or to all sentient beings". Those words perfectly suit the Mahayana doctrine of tulku as a Boddhisattva, a spiritual hero who works for the benefit of others with ultimate compassion and wisdom. Unfortunately, this lofty religious ideal, as Geshe pointed out, sometimes is not executed in daily life: "For the purpose of gaining properties or for other reasons, they succeed in being called tulkus". Therefore, in those passages, as in the previously presented ones, Geshe sees an inevitable discrepancy between the theory of tulku and how that theory works in social life. In my opinion, this is just one more proof of the criticism presented by Geshe towards the institution of tulku.

Generally speaking, Geshe Lhakdor presents himself in this interview as not only a Buddhist lama, a venerable teacher, but also as a critical observer of reality, who has both his feet on the ground. Commenting on the behaviour of tulkus, he states: "Not every tulku is necessarily a good person. In such cases, it is clear that they were wrongly chosen or that there is something wrong". On the other hand, he defends the traditional way of educating of tulkus, at least to some extent. As tulkus are not the reincarnations of the scientists, as he facetiously puts it, tulkus should be trained as Buddhists according to the traditional curriculum. However, some amendments to this system might be included, depending on the utility of scientific, non-Buddhist knowledge. "In the matter of the system of education, we should use our common sense and remain open-minded to adapt to what is best in both of those traditions".

This "liberal" approach continues through the next answers, where he was explaining the capacity of women to become tulkus or the cases of socalled "Western tulkus", children born outside Asia and then recognized as 
tulkus of Tibetan masters. However, during our conversation, I had a feeling that he would like to accept the occurrence of the former case more willingly than in the case of the last one. Then, in answering the question about "fallen tulkus" or those tulkus who abandoned the monastic vows and started to lead a lay life, he presents a very pragmatic approach, which respects, to some extent, the freedom of the person to make a choice, even if this choice is wrong from a Buddhist perspective. Nevertheless, again, when it comes to expressing comments on Buddhist doctrine on this particular case, he presents an orthodox view: "I mean that a genuine tulku can't fall. If you are a genuine reincarnation, let's say a monk, then, even if he disrobes... for example, he met a beautiful woman. Then, he is no longer a monk, but he is still a tulku".

\section{Ad 3: the political context of the institution of tulku}

Talking about the institution of tulku, one cannot omit the political context which bound it to the sphere of competition of political power and conflicts of interests. It is quite obvious that the institution of tulku, as one of the fundamentals of Tibetan Buddhism was, simply by the fact of its mere existence, incorporated into the world of "big politics". Anyone who investigates Tibetan history has little doubt about this, especially in the cases of high tulkus, who belonged to the hierarchy of Tibetan Buddhism and who were part of the Tibetan ruling class. Those issues are examined in literature; therefore, there is no reason to present it as a whole. Just two examples taken from Tibetan history can depict how the institution of tulku was subjugated to the fluctuations of politics. After the death of the 4 th Dalai Lama in 1617 , Jonten Gyatso, his political opponent, the ruler of Tsang Karma Phuntsok Namgyal (kar ma phun tshogs rnam rgyal) "[...] sternly decreed it unlawful to search for the reincarnation of the Fourth Dalai Lama, thus effectively blocking the foundation of the emerging political and spiritual spirit and stamina of Ganden Phodrang and Gelug supremacy". ${ }^{13}$ As we know, political history in Tibet took a different direction and the supremacy of Ganden Phodrang and the Gelug sect was soon established, at least in U and Tsang areas. Seven years before the official enthronement of the 5th Dalai Lama, Ngawang Lobsang Gyatso (ngag dbang blo bzang rgya mtsho), the head of Jonangpa (jo nang) lineage and respected scholar, Taranatha ( $t A \mathrm{ra} n A$ tha), passed away. Taranatha was a spiritual teacher of the same Karma Phunt-

${ }^{13}$ K. Dhondup, op. cit., p. 12. 
sok Namgyal, who actively tried to stop the lineage of Dalai Lamas. Then, in 1642 , in the year of triumph of the coalition of the Gelug sect and the army of the Mongolian Qosot leader, Gushri Khan (bstan 'dzin chos rgyal), the reincarnation of the Taranatha was recognized by the Gelugpas hierarchs. "The Mongolian child bLo bzang bstan pa'i rgyal mtshan (Lobzang Tenpe Gyaltsen 1635-1723), was claimed by the First Panchen Lama, the Fifth Dalai Lama and the State Oracle of Tibet to be re-embodiment (sprul sku) of Tāranātha, the First Khal kha rfe Btsun dam pa (Khalka Jetsun Dampa)". ${ }^{14}$ The appropriation of the Tāranātha tulku lineage by the Gelugpas for political reasons as well as earlier attempts of the Tsang ruler to wreck the lineage of the Dalai Lamas serve as a clear example of politics involved in controlling such spiritual traditions as the institution of tulku. There are many more instances of such activities which can be found in Tibetan history. This doesn't mean that I claim that the institution of tulku was totally corrupted by the politics and sectarian interests of particular religious traditions. However, we should be aware of the fact that high tulkus were simply part of the theocratic system of Tibet and for this reason investigating the history of its institutions inevitably leads us to the realm of politics.

It was necessary to present this short introduction before analyzing the third part of the interview, which is mainly focused on the political issues connected with the institution of tulkus. During the conversation, the matter of double choosing tulkus was discussed. This subject brought up the issue of double choosing Karmapas and Panchen Lamas.

Both topics are very sensitive for Tibetan Buddhists, as they shook the very foundation of the system of their religion. It also has to be taken into consideration that most Tibetans are Buddhists and the events connected with the double-recognition of tulkus directly relates to the world-view of these individuals. Therefore, for many of them, including some of my interlocutors, the discussion about the issue of double choosing was more than just commenting on the current policy of the government. Furthermore, this topic cannot be analyzed without considering the political situation of Tibetans as a nation without their own state. The practice of double choosing tulkus, both Karmapas and Panchen Lamas, has to be implicitly considered in the context of Tibet-China relationships with regard to this issue.

\footnotetext{
${ }^{14}$ M. R. Sheey, The Jonangpa after the Täranātha: auto/biographical writings on the transmission of esoteric Buddhist knowledge in seventeen century Tibet, p. 19.
} 
I am convinced that those remarks above concerning the doublechoosing of tulkus clearly correspond to the answers given by Geshe Lhakdor. Nevertheless, his approach to the cases discussed differs diametrically. In the case of double-choosing Karmapas, he relates to the Buddhist doctrine of possible multiple reincarnations of one deceased spiritual master, and he considers the whole controversy of double Karmapas as an outcome of the "blind faith" of the followers of Tibetan Buddhism. As a side note, I would say that I got the impression during the conversation, that Geshe is sincerely critical of this kind of blind devotion, which can be found within some circles of followers of Tibetan Buddhism. However, when it came to discuss of case of double Panchen Lamas, he started to be very firm in his criticism of the Chinese policy towards Tibetan Buddhism: "They clearly stated that there are two things which must to be destroyed to bring harmony between Tibetans and Chinese. Those two things are the Dalai Lama and Buddhism". Geshe has no doubts, that the case of recognition of the Panchen Lama by the Chinese authorities is a purely political issue and should be understood as one more attempt to entirely subjugate Tibetan Buddhism to the authority of the state. In answer to my question, as to who should be considered as a "real" Panchen Lama, he says: "The Panchen Lama recognized by the Dalai Lama is the correct one but in Tibet people are not even allowed to say something like that". This statement is another empathic voice of Tibetans in their struggle to preserve ancient Buddhist culture in their land.

\section{Ad 4: the future of the institution of tulku}

The short fragment of the interview, in which the future of the institution of tulku is discussed, clearly presents Geshe Lhakdor's view on this subject. He ironically comments that the institution of tulku will prevail in Tibetan culture, due to the demands of the followers of Tibetan Buddhism, who sometimes are led only by blind faith. This blind faith, which is duly criticized by Geshe Lhakdor, is the cause of the existence of "false" tulkus, who appeared on the religious market of ideas, and various spiritual gurus in India. "There will be always enough people who will believe in a particular reincarnation. Therefore, there is an opportunity for them to come. Good as well as bad. Good, because of their faith. They can serve, they can help; therefore, the right reincarnations can come. False reincarnations can also come, because it is a market".

Comments made by Geshe on the future of the institution of tulku, espe- 
cially with regard to the mentality of some believers, struck me by its sincerity and explicitness. In a few words, he made a controversial but, at the same time unequivocal analysis of the popularity of the institution of tulku among Tibetans. As I don't completely agree with his statement, due to the fact it is too simplified, at the same time I really appreciate this opinion as a valuable voice contributing to an explanation of the phenomenon of tulku. I would like to add that I feel a great respect towards Geshe Lhakdor as a teacher of Tibetan Buddhism and I am totally aware of the fact that, during our conversation, he merely touched on the subject of tulkus, presenting only part of his knowledge with regard to this subject. Nevertheless, although some of his statements seem to be controversial or one-sided, they, however, at the same time, remain inspiring.

\section{Ad 5: the concept of reincarnation}

The last part of the interview differs from the earlier parts with regard to the subject under discussion. Instead of talking about Tibetan culture, the conversation changed its course to a more general discussion about reincarnation and the nature of the mind. Apparently, this topic doesn't relate to the issue of institutional reincarnation in Tibetan culture, but, as a matter of the fact, forms the very core of it. During my interviews with Tibetans living in India, I observed that, for many of them, the question of the existence of an afterlife and reincarnation wasn't difficult to answer. Furthermore, this issue wasn't even questioned. "Reincarnation exists because the world exists", would sum up the unexpressed assumption of many of my interlocutors with regard to this topic. Therefore, sometimes, the question about reincarnation wasn't even considered a serious question or, what's worse, put me in the rather dubious position of a Western freak. For Geshe Lhakdor, the main proof of the existence of reincarnation is the accounts of people who describe their previous lives in detail: "But, a more powerful argument for the afterlife is the fact that some people simply remember their past reincarnations". Such reliance on the accounts of other people is characteristic of a non-scientific approach to problems to be solved. In Buddhism, the charisma of the particular master determines his popularity among his followers. Personal "realisation" on the spiritual path determines his or her credibility as a trustworthy person. I am far from criticizing this approach, by saying that the present scientific paradigm of investigation is totally correct. To tell you the truth, I think that 
it is actually not so, because it dismisses a vast scope of phenomena as being scientifically unproven, including reincarnation, telepathy and clairvoyance. ${ }^{15}$ What I am saying is that the phenomena of reincarnation, for many of Tibetans, doesn't demand any investigation, and this approach I would reject with the same strength as I don't approve the view that so-called parapsychology is beyond the scope of interest of scientific investigation. Both approaches exclude reincarnation as a subject of rational and experimental investigation.

From a Tibetan perspective, this "non-investigative" approach directly transfers to their culture and creates some quite paradoxical and interesting outcomes with regard to the institution of tulku under discussion. Many of the young Tibetans whom I interviewed consider themselves as "critical Buddhists", who follow the advice of H. H. Dalai Lama to investigate the validity of the particular assumptions of Tibetan religion. However, they are Buddhist, and, as a such, I mean genuine Tibetan Buddhists; they believe in reincarnation. Since they believe in reincarnation, they should also believe that phenomena such as tulkus exist. It is a "logical" continuation of the previously approved assumption of the existence of reincarnation. Therefore, a clear paradox arises from it.

On the one hand, they accept that tulkus exist; in other words, they accept the existence of such unusual beings, who can plan their rebirth, which means that they had developed their minds to such an extraordinary level, which allows them to overcome the darkness of the state of bardo. On the other hand, they criticize more or less openly the credibility of those people as leaders of their society. I think, that the source of such contradiction lies in the fact that Tibetan culture in exile is in a kind of liminal state, and it is exposed to strong secularization processes. The culture, which is strongly bound with religion in the Tibetan case, serves as a necessary source of identity for a people deprived of their country. This is why Tibetans in exile try to preserve the traditional values of their culture and bestow a kind of cultural duty to be fulfilled on the new generation.

When a young, well-educated Tibetan is asked about the institution of tulku, he or she, as a Buddhist, has to confirm the possibility of their existence as a genuine reincarnation of the deceased lama. However, these days,

${ }^{15} \mathrm{M}$. Woch, Telepatia $w$ snach - międzykulturowy fenomen. Relacje $z$ telepatycznych kontaktów zachodzących we śnie przekazane przez Kazimierza Chodkiewicza, oraz zapisy podobnych doświadczeń w tradycji buddyzmu tybetańskiego, pp. 180-193. 
most of the tulkus are not considered as individuals whose intellectual capacities are beyond the comprehension of commoners. In the past, tulkus were regarded as unusual children with special abilities to learn things in a quicker way than others. Therefore, they were acknowledged by the ordinary people as akin to deities or gods, embodied in the human form. Nowadays, the institution of tulku has desacralized itself, due to various causes. One of those causes, as mentioned above, is the slow but visible process of the secularization of Tibetan culture, the other is the behaviour of the tulkus themselves. The conduct of particular tulkus, the way they were recognized, their wealth and, unfortunately, some scandals which were publicized by the media - all of this contributes to the process of contesting their sacredness and uniqueness. This is why Tibetans have a problem with tulkus. They cannot dismiss the institution of the tulku, because of the fact that it is based on a principle of Tibetan Buddhism, which is the conviction that some people can have a controlled rebirth. And, I must add, that, in my opinion, the majority of Tibetan Buddhists believe that there are still genuine tulkus, such as, for example, H. H. Dalai Lama. However, there are thousands of tulkus who do not present such spiritual accomplishments and, according to the words of one of the lamas interviewed, they differ from ordinary people only by the fact that they travel through India in AC class.

Returning to the interview with Geshe Lhakdor, I think that what was mentioned above, as the opinion of lay people on the topic of tulku institution, also relates to the opinion of at least part of the Buddhist hierarchy. Tulkus are criticized for various reasons; however, the fundamentals of the doctrine cannot be criticized, because of the fact that it is at the core of Buddhist Mahayanic doctrine. In other words, the assumption that tulkus exist is not undermined by Tibetans, unless science proves that reincarnation doesn't happen, but, at the same time, the fact that the institution of tulku has degenerated over recent decades shouldn't be hidden. Even if we take into consideration some political reasons which may lay behind of criticism presented by the Tibetans with regard to the institution of tulku. 


\section{Bibliography}

1. Asshauer E., Tulkus - The Mystery of the Living Buddhas, Fabri Verlag, Ulm/Donau 2006.

2. Barlocher D., Testimonies of Tibetan Tulkus, Vol 1-2, Tibetan Monastic Institute Rikon/Zürich, Zürich 1984.

3. Berounsky D., Entereing dead bodies and the miraculous power of the Kings: The landmark of Karma Pakshi's reincarnation in Tibet. Part I, "Mongolo-Tibetica Pragensia", t. 3, nr 2, TRITON, Prague 2010, pp. 7-33.

4. Dhondup K., The Water Horse and Other Years, LTWA, Dharamsala 2003.

5. Dzongsar Jamyang Khyentse Rinpoche, Time for Radical Change in How We Rise Our Tulkus, "Tricycle", [www 01].

6. Goldstein M., The Circulation of Estates in Tibet: Reincarnations, Land and Politics, "The Journal of Asian Studies", Vol. 32, No. 3, AAS, Ann Arbor, May, 1973, pp. 445-455.

7. Hanzhang Ya, Biographies of the Tibetan Spiritual Leaders, Foregin Language Press, Beijing 1994.

8. Indo-Tibetan Relations: Shared Heritage Shared Future, CTA, Dharamsala.

9. Ishinama Y., On the dissemination of the belief in the Dalai Lama as the manifestation of the Bodhisattva Avalokiteśvara, "The History of Tibet", Vol 2, Routledge Curzon, London/New York 2003, pp. 538-552.

10. Kapstein M. T., Tybetańczycy, tł. J. Hunia, WUJ, Kraków 2010.

11. Oldtmann M., Forging the Golden Urn, Columbia Univeristy Press, New York 2018.

12. Ray R. A., Some Aspects of the Tulku Tradition in Tibet, "The Tibet Journal" 11/4, Dharamsala 1987, pp. 35-69.

13. Serta Tsultrim, The Glowing Legacy, Dharamsala 2009.

14. Sheey M. R., The fonangpa after the Täranātha: auto/biographical writings on the transmission of esoteric Buddhist knowledge in seventeen century Tibet, "Bulletin of Tibetology" 45.1, Namgyal Institute of Tibetology, 2010.

15. Slobodnik M., A Difficult Rebirth: Tibetan Reincarnations in the Spotlight of Chinses Religious Policy, "Studia Orientalia Slovaca", Department of East Asian Studies, Comenius University in Bratislava, t. 10, nr 1, 2011, pp. 57-80. 
16. Wocн M., Telepatia w snach - międzykulturowy fenomen. Relacje z telepatycznych kontaktów zachodzacych we śnie przekazane przez Kazimierza Chodkiewicza, oraz zapisy podobnych doświadczeń $w$ tradycji buddyzmu tybetańskiego, "Studia ezoteryczne", WUJ, Kraków 2016, pp. $180-193$. 